Marek Świder Akademia Ignatianum w Krakowie

Maria Marta Urlińska Akademia Ignatianum w Krakowie

\title{
Prywatne Gimnazjum Sanatoryjne Męskie dr. Jana Wieczorkowskiego w Rabce (1924-1939)
}

Dr. Jan Wieczorkowski's Men Sanatorium High School in Rabka (1924-1939)

\begin{abstract}
ABSTRAKT
W roku 1924 powstała w Rabce szkoła przeznaczona dla uczniów chorych przybywajacych do uzdrowiska na leczenie sanatoryjne. $\mathrm{Ni}$ niejszy artykuł prezentuje idee i rozwiqzania proponowane przez Gimnazjum Męskie Sanatoryjne dr. Jana Wieczorkowskiego w Rabce. Wykorzystano materiały dostępne w Archiwum Państwowym oraz archiwum szkolnym LO im. E. Romera w Rabce-Zdroju. W tekście odwołano się także do wspomnień byłych uczniów tej placówki, wydanych drukiem bqdź opublikowanych na stronach internetowych. Zostały pokazane społeczne uwarunkowania powoływania pierwszych placówek szkolnych na tych terenach oraz zapotrzebowanie w tym środowisku na działania oświatowe w latach poprzedzających założenie szkoły sanatoryjnej. Udokumentowana została historia instytucji, pokazana jej specyfika, wraz z programem nauczania czy
\end{abstract}

SLOWA KLUCZOWE gimnazjum, szkoła sanatoryjna, szkolnictwo państwowe i prywatne, kształcenie w okresie międzywojennym, leczenie uzdrowiskowe

\section{KEYWORDS}

junior high school, sanatorium school, public and private education, education in the interwar period, spa treatment

SPI Vol. 19, 2016/2

ISSN 2450-5358 e-ISSN 2450-5366 DOI: 10.12775/SPI.2016.2.011

Artykuły i rozprawy 
podporzqdkowanq leczeniu organizacia pracy szkoły. Zaprezentowano charakterystykę postaci zwiqzanych z tą placówkq (dyrektora, nauczycieli i uczniów), pokazano zależność między jakościq pracy szkoły a wynikami uczniów przybyłych na krótszy lub dłuższy okres do rabczańskiego zdrojowiska. Wskazano na przyczyny sukcesu szkoły, jaki niewqtpliwie został osiq̨gnięty w tej niewielkiej miejscowości w trudnych latach międzywojnia. W centrum działalności szkoły ukazano postać założyciela, właściciela i dyrektora tej placówki, jego pomysł na organizację nauki w trakcie procesu leczenia, oraz ideę wykorzystania walorów tego szczególnego miejsca, w którym szkoła funkcjonowała.

\section{ABSTRACT}

In 1924 an educational institution for students who were patients coming for the sanatorium treatment was established in Rabka, a spa city. This article presents the ideas and solutions proposed by the Dr. Jan Wieczorkowski's Men Sanatorium High School in Rabka. The text is based on the material available in the State Archives and in the E. Romer's High School Archive in Rabka-Zdrój. The reminiscences of the former students of this institution which were published, posted on websites and gathered during interviews, were also taken into account. The social conditions of the first of the schools in those regions and the public demands for educational activities in the years preceding the establishment of the sanatorium school in Rabka were discussed too. The article documents the history of the institution, showing its unique features, including the curriculum and the organization of school work, which was subordinated to the treatment. Some characteristics of the persons associated with this institution (director, teachers and students) were also depicted. Thereby the text shows the relationship between the quality of the school work and the results gained by students who used to come to Rabka for a shorter or longer period. The article points out the reasons for the success of this school which undoubtedly has been achieved in this small town in the difficult years of the interwar period. The central figure was the school's founder, director and owner of this institution. His idea to organize the learning process during the treatment and to take advantage of this special and unique place were also demonstrated. 


\section{Z historii miasta, uzdrowiska i miejscowego szkolnictwa}

Rabka-Zdrój to miejscowość górska położona nad rzeką Rabą i jej dopływami: Słonką i Poniczanką, na pograniczu Beskidu Wyspowego i Gorców. Samo miasto liczy obecnie 12993 mieszkańców, natomiast trzy wioski wchodzące w skład gminy zamieszkuje 4362 osób ${ }^{1}$. Miejscowość jest usytuowana w pięknej, zalesionej kotlinie położonej na wysokości 500-600 m n.p.m. Jej klimat jest dużo łagodniejszy niż górski, panujący w tych rejonach, przeważa aura $\mathrm{z}$ małą ilością słabych, głównie zachodnich wiatrów, dużym nasłonecznieniem i stosunkowo niewielką ilością opadów oraz niewielkich skoków temperatury. Nie ma także ostrych mrozów ani nadmiernych upałów, a to wszystko sprawia, że warunki do życia są tu przyjazne, zwłaszcza dla przybywających na leczenie i wypoczynek kuracjuszy. Te walory środowiska geograficznego i przyrodniczego, klimatu, nasłonecznienia, górskiej roślinności, pięknych widoków oraz bogactwo wód solankowych sprawiło, że odkryta dla leczenia uzdrowiskowego w okresie międzywojennym Rabka dokonała nieprawdopodobnego skoku w swoim rozwoju.

Historia tej miejscowości sięga 1740 roku, kiedy to klucz rabczański z wsiami: Chabówka, Ponice, Rabka, Rdzawka, Skomielna, Słone i Zaryte otrzymał starosta lanckoroński hrabia Józef Wielopolski, herbu Starykoń. Ostatni z tego rodu - Wincenty na Ślemieniu, sprzedał ziemie Józefowi Zubrzyckiemu, herbu Wieniawa. W tamtych czasach były to tereny słabo zaludnione, a tego dowiadujemy się z pierwszego spisu mieszkańców, którego dokonał w 1829 roku ówczesny proboszcz parafii, a jednocześnie brat Józefa Zubrzyckiego - właściciela Rabki ${ }^{2}$ W 1855 roku ziemie te po zmarłym przod-

1 Dane na dzień 2.02.2015 roku, <http://www.rabka.pl/index.php?dzial=3>.

2 Z tego źródła dowiadujemy się, że w roku 1829 parafię zamieszkiwało 4906 wiernych, w należących do niej wsiach: Rabka (1027), Skomielna (734), Zaryte (563), Słonne (683), Ponice (749), Rdzawka (645), Chabówka (505). K. Kowalczyk, Miejsca kultu religijnego w Rabce Zdroju, Kraków 2003, s. 40. W 1880 roku parafia rzymskokatolicka św. Marii Magdaleny liczyła około 7300 wiernych zamieszkujących wymienione powyżej wsie, do których dołączyła jeszcze Skawa. H. Urbanowski, Takie byty Zdroju początki, w: K. Ceklarz, J. Ceklarz, J. Gaweł, P. Kuczaj, H. Urbanowski, Rabka. Ztote lata Rabki Zdroju, Rabka-Zdrój 2014, s. 42. W latach 1935-1939 ludność Rabki liczyła od 6324 do 8633 mieszkańców. 
ku odziedziczył Julian Antoni Stanisław Zubrzycki i jemu to Rabka zawdzięcza swój intensywny rozwój przypadający na lata 1855-1892. Nowy właściciel w 1864 roku otworzył tu pierwszy piętrowy zakład kąielowy wraz z łazienkami. Wówczas to, chociaż były to trudne czasy zaborów, Rabka rozwijała się dynamicznie i zajmowała z roku na rok coraz bardziej znaczące miejsce na mapie uzdrowisk europejskich. Do tego zdrojowiska przyjeżdżali kuracjusze z całej Polski, stawał się on bardzo modnym miejscem wypoczynku. Po śmierci Juliana ${ }^{3}$ Zubrzyccy byli w posiadaniu tych terenów jeszcze przez trzy lata, po czym zbyli majątek, sprzedając go znanej i zasłużonej w Polsce rodzinie Kadenów, która w 1895 roku odkupiła prawa własności do Rabki.

Od tej pory datowany jest czas największej prosperity miejscowości. Od początku dr Kazimierz Kaden był przekonany o walorach leczniczych wód solankowych, jakich natura nie poskąpiła Rabce, zainwestował więc wszystkie swoje pieniądze w badania geologiczne, odwierty i wydobycie solanki oraz rozbudowę miejscowego zakładu leczniczego. Uczynił to z przekonaniem, że miejsce warte jest tego wysiłku, a dzieło rozbudowy uzdrowiska stało się celem i sensem jego życia.

Dzięki odkrytym w okresie międzywojennym źródłom solankowym Rabka, jako uzdrowisko dziecięce i kurort, cieszyła się międzynarodowa sławą, panowało przekonanie, że „należało w niej bywać”. Odnotowywano więc niezwykłą dynamikę przyrostu kuracjuszy. Znaczący jest fakt, że w 1914 roku mieszkańcy Rabki gościli 6729 kuracjuszy, 20 lat później już 20339 , natomiast w 1938 roku potrafili przyjąć 27452 osób, czyli cztery razy więcej wczasowiczów niż w 1914 roku. Źródła donoszą, że tuż przed wybuchem II wojny światowej w Rabce przebywało prawie czterokrotnie więcej kuracjuszy niż stałych jej mieszkańców (statystyki z 1939 roku podają liczbę 30153 osób okresowo przebywających w uzdrowisku) ${ }^{4}$. O rozwoju miejscowości w okresie przed II wojną światową świadczyła jej rozbudowywana infrastruktura. Liczba willi i pensjonatów przeznaczonych dla kuracjuszy dynamicznie się zwiększała, mieszkańcy brali kredyty i przygotowywali nowe budynki mogące przyjąć chętnych, którzy chcieli odpoczywać i leczyć się w uzdrowisku. Widać było, że

3 Julian Zubrzycki zmarł 8 stycznia 1892 roku.

4 Zob. Historia Uzdrowiska Rabka, cz. 2, <http://www.rabka.pl/index.php? dzial=2\&dok=2> [dostęp: 20.09.2016]. 
zaczęto inwestować w nieruchomości (w przewodniku rabczańskim z 1938 roku odnotowane jest oddanie do dyspozycji gości 230 willi i pensjonatów położonych w tym uzdrowisku) ${ }^{5}$.

W tej to właśnie miejscowości uzdrowiskowej powstała instytucja edukacyjna przeznaczona dla chorych uczniów przybywających do Rabki na leczenie sanatoryjne. Przed zaprezentowaniem idei i rozwiązań proponowanych przez założyciela szkoły sanatoryjnej, należy pokazać jak ubogie oświatowo było to środowisko, jakie były społeczne uwarunkowania powoływania pierwszych placówek szkolnych na tych terenach, jakie było zapotrzebowanie na działania oświatowe w latach poprzedzających założenie szkoły sanatoryjnej.

Otóż dosyć późno, bo dopiero w 1835 roku, syn dziedzica Józefa Zubrzyckiego, ksiądz Tomasz Zubrzycki założył w Rabce pi e rw szą szkółkę parafialną, w której uczył miejscowe dzieci religii, czytania, pisania i liczenia ${ }^{6}$. Źródła podają, że w roku 1854 na tym terenie działało siedem małych szkółek parafialnych; w Skawie, Skomielnej, Zarytem, Słonnem, Habówce [Chabówce], Rdzawce, Skomielnej i Ponicach (jedynie dwie ostatnie z wymienionych placówki posiadały już wtedy własne budynki). Dzieci pobierały naukę w czasie zimy, często przychodziły na lekcje niesystematycznie. To głównie decydowało o niskim poziomie nauczania, jednak dodatkowym utrudnieniem była słabo przygotowana kadra nauczycielska. W szkółkach uczyli nieco tylko bardziej wyedukowani miejscowi chłopi, a to sprawiało, że poziom nauczania był bardzo niski. Wszystko to decydowało o tym, że nierzadko po zakończonej edukacji uczniowie nie umieli się nawet podpisać.

W 1875 roku w miejsce szkoły parafialnej utworzono w Rabce pierwszą szkołę powszechną, pospolitą i etatową, która była utrzymywana przez gminę. Szkoła mieściła się w „organistówce” w pobliżu kościoła (była to jedna sala lekcyjna). W 1890 roku na jej potrzeby oddano nowy budynek już z dwiema salami lekcyjnymi, mieszkaniem dla nauczyciela i małym pokojem na poddaszu. Dopiero w 1916 roku szkoła ta stała się 5-klasowa ${ }^{7}$. Poziom oświaty

5 E. Nawratil, C. Trybowski, Rabka i okolice oraz krótki przerwodnik po Beskidzie Wyspowym i Gorcach, Kraków 1938.

6 K. Kowalczyk, Miejsca kultu religijnego w Rabce Zdroju, Kraków 2003, s. 40-44.

7 A. Czarnecka, Historia szkoty, <http://www.sp2.rabka.p1/historia/historia. html>, [dostęp: 20.09.2016]. 
w sąsiednich wsiach prezentował się jeszcze gorzej. Szkoły powszechne powstawały kolejno w Słonnem (1896), Skomielnej (1885), Ponicach (1906), Habówce (1908), Rdzawce (1909), Zarytem (1926) oraz w Skawie (1929). Były to najczęściej szkółki jednoklasowe.

Powołanie do życia pierwszej w środowisku szkoły mającej status s zkoł y gi m na zja ln ej należy wiązać z faktem przybycia do Rabki w 1915 roku Jana Wieczorkowskiego ${ }^{8}$, który został zatrudniony przez zamożnego właściciela Rabki dra Kazimierza Kadena w charakterze prywatnego nauczyciela jego dzieci. Już w rok po podjęciu pracy młody Jan poślubił córkę swojego pracodawcy, starszą od siebie o kilka lat, zakochaną w nim Helenę. Młodzi małżonkowie w posagu otrzymali od Kadenów dwie wille: „Luboń” i „Pod Białym Orłem”. Wynajmowanie jednej z nich przyjezdnym kuracjuszom, i to tylko w okresie letnim, nie przynosiło Wieczorkowskim stałych dochodów umożliwiających życie na odpowiednim do statusu społecznego poziomie. Sytuacja stała się jeszcze trudniejsza, gdy na świat przyszedł ich syn, Jan Wieczorkowski junior. Konieczne było, aby ojciec i głowa rodziny znalazł posadę, która dawałaby mu możliwość utrzymania żony i dziecka.

Doktor Jan Wieczorkowski okazał się być wielkim wizjonerem, kiedy to wyczuwając koniunkturę i wykorzystując fakt dynamicznego rozwoju uzdrowiska (szczególnie jego popularność, a co za tym idzie znaczną liczbę przebywających w nim kuracjuszy), w 1924 roku

8 Jan Leon Emil Wieczorkowski urodził się 20 lutego 1891 roku w Krakowie, w dokumentach zostało odnotowane jego rzymskokatolickie wyznanie, narodowość polska, obywatelstwo Austrii. Opiekunem jego był Jakub Chrząszcz, kapitalista zamieszkały w Krakowie-Podgórzu. Jan ukończył Gimnazjum św. Jacka w Krakowie, zdając maturę w dniu 27 maja 1909 roku. Rozpoczął studia na Uniwersytecie Jagiellońskim, a w dokumentach wpisany został jako „student zwyczajny”, pobierający naukę na Wydziale Filozoficznym w latach 1909-1914. Od sierpnia 1914 do listopada 1918 roku był wcielony do armii austro-węgierskiej, a po odzyskaniu niepodległości wstąpił do polskiego wojska, służąc w nim od listopada 1918 do listopada 1920 roku. W dniu 5 listopada 1921 roku zdał państwowy egzamin nauczycielski i uzyskał uprawnienia do nauczania języka polskiego jako przedmiotu głównego oraz filologii klasycznej jako przedmiotu pobocznego w szkołach średnich z językiem wykładowym polskim. Powrócił na studia uzyskując absolutorium w dniu 3 marca 1922 roku. Po kolejnym roku studiów uzyskał doktorat z filozofii (z filologią polską) na podstawie rozprawy: Twórczośc dramatyczna Niemcewicza, którą obronił w dniu 28 czerwca 1923 roku. M. Olszewska, E. Trybowska, Stownik biograficzny Rabki, Kraków - Rabka Zdrój 2012; Akta osobowe J. Wieczorkowskiego, studenta UJ w Krakowie, Archiwum WF UJ w Krakowie. 
założył gimnazjum dla chłopców przebywających w Rabce na leczeniu uzdrowiskowym. Osoba dr. Wieczorkowskiego jest kluczowa dla powstania i funkcjonowania tej szkoły. Zdzisław Olszewski w swych wspomnieniach tak opisuje założyciela szkoły i swojego nauczyciela:

[...] był mężczyzną harmonijnej budowy ciała, proporcjonalnej do średniego wzrostu, ale tak nieprzeciętnej urody (artysty filmowego), energii i pełni życia, brunetem, że panna Helena Kadenówna zakochała się w nim bez pamięci. Zdaniem pozostałych członków rodziny Kadenów współwłaścicieli Rabki, popełniła mezalians, wychodząc za mąż za pana Jana [...] był nie tylko pięknym mężczyzną, lecz także arbitrem elegancji w całej okolicy. Wszystko co nosił pochodziło z najlepszych magazynów krajowych i zagranicznych [...]. Na premiery w teatrze Słowackiego jeździli państwo Wieczorkowscy własną lancią [...] był czarującym rozmówcą, kompanem dowcipnym, człowiekiem skłonnym do uśmiechu i radości. Potrafił smucić się rozsądnie i cieszyć bez granic. Wszystko widział, rozumiał, analizował - dysponował ogromną wiedzą i pamięcią. Podróżował po całej Europie?.

\section{Szkoła Dr. Jana Wieczorkowskiego - nowe spojrzenie na edukację realizowanq w warunkach sanatoryjnych}

Za sprawą dr. Jana Wieczorkowskiego powstała więc w Rabce placówka specyficzna, realizująca, oprócz terapeutycznych, cele edukacyjne. Zadania, jakie stały przed szkołą, określał wydany przez jej założyciela prospekt reklamujący walory miejsca oraz przybliżający ideę szkoły. W rozdziale „Powstanie Zakładu, jego cele i rozwój” czytamy:

Urzeczywistniając myśl wielu wybitnych pedagogów i lekarzy, którzy domagają się, aby szkoła znajdowała się na świeżym powietrzu (poza miastem, w lesie, w okolicach górskich), oraz spełniając życzenia tej części społeczeństwa, która pragnie wychować swe dzieci w warunkach pod każdym względem najlepszym, otwarto w Rabce w 1924 roku gimnazjum połączone ściśle ze stosownie zorganizowanym internatem. Powstanie szkoły na świeżym powietrzu, na wsi, w górskiej miejscowości, będącej sławnym w Polsce zdrojowiskiem i uzdrowiskiem dla młodzieży, spowodowało, iż Zakładowi nadano charakter s z k o ł y le c zn i c z ej. Wskutek tego głównym celem szkoły, realizowanym od początku jej istnienia, było i jest połączenie nauki ucznia z jego leczeniem, co daje się pomyślnie przeprowadzić dzięki istniejącym w Rabce warunkom. Dla-

9 Z. Olszewski, Michat od Cyganów, Kraków 1985, s. 110. 
tego też do tutejszego Gimnazjum przyjmuje się w pierwszym rzędzie uczniów nie mogących wskutek wątłego zdrowia uczęszczać do szkół publicznych w mieście, gdyż wpływa to na ich ustrój szkodliwie. Uczniowie ci, ucząc się, mogą kształcić się dzięki miejscowym warunkom bez szkody dla zdrowia (czyste, górskie, łagodne powietrze, dużo słońca, lasy, łagodna zima) - co więcej, przeprowadzając zaleconą im przez lekarza kurację, ugruntowują na przyszłość swój stan zdrowia, uodporniając i hartując słabowity lub wątły organizm. Pobyt w Rabce przynosi uczniom nie tylko pomyślne rezultaty lecznicze; gimnazjum tutejsze może się poszczycić również dobrymi wynikami w zakresie nauczania szkolnego, oraz rezultatami na polu racjonalnego wychowania młodzieży. [...] Pomyślny swój rozwój zawdzięcza szkoła nie tylko samej miejscowości, wyjątkowej pod względem leczniczym, zwłaszcza dla młodzieży w wieku szkolnym (cały rok łagodny górski klimat, kąpiele jodowo-solankowe, gazowe, borowinowe, inhalacje itp.), lecz także dobrym warunkom umieszczenia, oraz umiejętnemu prowadzeniu szkoły i internatu ${ }^{10}$.

Była to pierwsza tego typu szkoła w Polsce. Została zarejestrowana początkowo pod nazwą: Zakład Naukowo-Wychowawczy z Internatem „Rabka Dwór”, następnie działała pod szyldem: Szkoła Średnia Męska Sanatoryjna dr. Jana Wieczorkowskiego w Rabce. Rodzina Kadenów przeznaczyła na potrzeby tej placówki część swego majątku, a był to okazały budynek rabczańskiego dworu, wokół niego ponad dwa hektary parku, pomieszczenia gospodarcze wraz z lamusem. Opis tej nieruchomości, ze wskazaniem na jej walory, który został zamieszczony we wspomnianym prospekcie szkoły, najlepiej pokazuje jakich zmian dokonano i w jaki sposób adaptowano przestrzenie zabudowań dworskich do potrzeb tworzonej instytucji edukacyjnej:

Gimnazjum mieści się w obszernym, murowanym jednopiętrowym domu („Dwór w Rabce”), oraz w przylegających budynkach, które rozbudowuje się w miarę rozwoju zakładu. Wszystkie budynki położone są wśród pięknego starego parku, z którym łączy się ogród warzywno-owocowy. W budynku głównym mieszczą się na parterze: pracownie szkolne, oraz bawialnia, jadalnia, biblioteka, umywalnie, łazienka i kuchnia, na piętrze: internat (sypialnie, umywalnie i łazienki), w pobliżu leżących budynkach: pracownie szkolne, świetlice, ściśle izolowana infirmeria ${ }^{11}$,

10 Prospekt Gimnazjum Męskiego Sanatoryjnego z Internatem dr. J. Wieczorkowskiego w Rabce, w archiwum LO im. E. Romera w Rabce.

11 Infirmeria (łac. Infirmus - słaby, chory) - sala przeznaczona dla chorych w budynkach zamieszkiwanych przez duże grupy osób, tutaj: w internacie szkoły. 
oraz mieszkania dla profesorów. Resztę zabudowań przeznaczono na mieszkania służb, pralnię oraz dla celów gospodarstwa rolnego, mlecznego i ogrodowego. Zakład bowiem prowadzi własne gospodarstwo rolne, mleczne i warzywnictwo, dzięki czemu tutejsi uczniowie otrzymują zdrowy nabiał i dostateczną ilość jarzyn. W parku szkoły wzniesiono obszerną, murowaną, krytą leżalnię, gdzie uczniowie werandują. W parku też urządzono boisko do gier i sportów (tenis, siatkówka, koszykówka itp.), część zaś ogrodu przeznaczono na cele naukowo-przyrodnicze (ogródek szkolny) ${ }^{12}$.

Integralną częścią szkoły był internat, w którym mogło jednorazowo przebywać co najwyżej 40 uczniów. Głównym jego zadaniem było „zastąpienie uczniom domu rodzicielskiego” poprzez wszechstronną opiekę, dbanie o stan zdrowia, kształcenie i wychowanie oddanych pod opiekę szkoły uczniów. Wychowankowie otrzymywali całodobowe utrzymanie, w tym: noclegi, wyżywienie, pranie, naprawę bielizny i garderoby oraz opiekę lekarską. Przyjmowano do szkoły uczniów, których stan zdrowia wymagał odpowiednich warunków higienicznych, stąd nad zdrowiem wychowanków i jakością (czystością) oddanych im do dyspozycji pomieszczeń czuwał lekarz internatowy.

Każdy przyjęty do zakładu uczeń musiał przywieźć ze sobą następującą, odpowiednio znaczoną wyprawkę: kołdrę, poduszkę, koc, białą kapę na łóżko, najmniej dwa ubrania na co dzień, jeden mundur i płaszcz mundurowy uszyty według wzoru używanego w gimnazjum państwowym, trzy pary butów, sweter, pantofle, dwie pidżamy, trzy garnitury bielizny pościelowej, sześć zmian bielizny osobistej, prześcieradło kąpielowe, gąbkę, przybory do mycia, grzebień i szczotkę do włosów, oraz nóż, widelec, łyżkę, łyżeczkę i leżak. Na zimę palto lub futro, worek futrzany do werandowania, grube buty narciarskie ${ }^{13}$.

Rytm dnia uczniów tej szkoły był ściśle określony, przebiegał według następującego harmonogramu: o godzinie 7.00 pobudka, następnie pól godziny przeznaczone na mycie z zabiegami leczniczymi, takimi jak zmywanie solankowe czy płukanie gardła solanką oraz ubieranie się, następnie apel połączony z modlitwą. O 7.30 w programie przewidziano 15 minut na śniadanie, po nim kolejne

12 Prospekt Gimnazjum Męskiego Sanatoryjnego z Internatem dr. J. Wieczorkowskiego w Rabce, dz. cyt.

13 Statut internatu Prywatnego Gimnazjum Męskiego dr. Jana Wieczorkowskiego, w archiwum LO im. E. Romera w Rabce. 
15 minut na gimnastykę przedlekcyjną. Od godziny 8.00 zaczynały się zajęcia dydaktyczne, które trwały po 40 minut, ostatnia szósta lekcja kończyła się o godz. 13.15. Przerwy między lekcjami wynosiły od 5 do 10 minut, na drugie śniadanie przeznaczano 15 minut. O godzinie 13.30 zaplanowano obiad poprzedzony krótką modlitwą. Popołudnie (15.00-16.30) przeznaczone było na wspólny spacer połączony z uprawianiem sportu oraz na zabiegi: lampa kwarcowa, gimnastyka ortopedyczna, a w lecie kąpiele solankowe, gazowe, borowinowe, inhalacje i inne temu podobne, na podwieczorek uczniowie przychodzili o 16.30, a po nim przewidziano mierzenie temperatury. Dwie kolejne godziny (17.00-19.00) uczeń spędzał na przygotowaniu lekcji na następny dzień, a robił to pod okiem dyżurującego profesora. Wieczór w internacie rozpoczynało mycie rąk, po nim kolacja z modlitwą i zażywanie przez uczniów lekarstw. Plan dnia przewidywał także godzinę na prowadzone w czytelni i świetlicy zabawy i gry (19.30-20.30), po tym 10 minut na sprawdzanie listy uczniów oraz modlitwę wieczorną. Kolejne 35 minut zajmowało przygotowanie się do spania (rozbieranie się, mycie, wyznaczone zabiegi lecznicze oraz kąpiel). Dzień ucznia w internacie kończył się o $21.15^{14}$.

\section{Nauczyciele i baza dydaktyczna jako istotne elementy sukcesu szkoły}

Założona szkoła była prywatnym przedsięwzięciem o charakterze komercyjnym, rodzice uczniów płacili bardzo wysokie czesne ${ }^{15}$. Właściciel szkoły zdawał sobie sprawę, że musi zadbać o renomę placówki, przyciągnąć do niej jak najwięcej uczniów. Wiedział, że pozycję szkoły wyznaczają nie tylko warunki nauki oraz program nauczania, ale także realizujące go kadry, stąd starannie dobierał nauczycieli do współpracy. Osobiście rekrutował ich, zachęcając nieco wyższym wynagrodzeniem niż proponowały inne prywatne gimnazja $\mathrm{w}$ okolicy, proponował przyjezdnym pedagogom służbowe

14 Tamże.

15 W latach 30. wynosiło ono 250 zł miesięcznie, mniej więcej tyle, co dwie pensje kolejarza czy nauczyciela. H. Urbanowski, Poczq̨tki dziatalności Liceum Ogólnoksztatcacego im. E. Romera w Rabce-Zdroju. Szkota z tradycja, „Wieści Rabczańskie"2014, nr 1(17), s. 10-11. 
mieszkania w oficynie dworskiej. Przed zatrudnieniem przyglądał się kwalifikacjom, oceniał także ich zaangażowanie w wykonywaną pracę. Zdzisław Olszewski, były uczeń, wspomina swoich nauczycieli następująco:

Pedagogami w naszym Dworze byli przeważnie ludzie młodzi, ale uzdolnieni i dobrze znający swój przedmiot wiedzy, często się zmieniali w Oficynie. Nagle przyjeżdżali - szybko wyjeżdżali. A zjeżdżali się z całego kraju, przede wszystkim z Krakowa, gdzie większość studiowała na Uniwersytecie Jagiellońskim. Sumiennie za to dobierał [dyrektor] pedagogów - najzdolniejszych wśród zdolnych spośród zgłoszonych kandydatów. Dostawali miesięcznie około 200 złotych brutto, ale po potraceniu czynszu za mieszkanie w Oficynie, za internetowy wikt, oraz inne jeszcze świadczenia, kilkadziesiąt złociszów mniej (dla porównania bilet kolejowy trzeciej klasy z Rabki do Krakowa kosztował wtedy 7 zł ${ }^{16}$.

W początkowej fazie działalności gimnazjum nauczyciele zmieniali się bardzo często. Grono pedagogiczne, oprócz dyrektora, w danym roku liczyło przeważnie 10 profesorów. W dokumentach znajduje się potwierdzenie dużej fluktuacji kadr. W stosunkowo krótkim, 14-letnim okresie funkcjonowania gimnazjum $\mathrm{w}$ okresie międzywojennym przewinęło się przez szkołę 32 nauczycieli ${ }^{17}, \mathrm{w}$ tym trzech z tytułami doktora: dr Jan Wieczorkowski (dyrektor i założyciel gimnazjum, uczył języka niemieckiego, często zastępował nieobecnych w pracy nauczycieli języka polski, historii i łaciny), dr Włodzimierz Holejko (długoletni nauczyciel łaciny i języka niemieckiego, przyszły dyrektor tej szkoły), dr Zygmunt Karpiński (pracujący bardzo krótko w szkole, nauczyciel języków: francuskiego i niemieckiego $)^{18}$. Kilku nauczycieli miało jednak dłuższy okres zatrudnienia w tej placówce, do osób z najdłuższym w Spytkowicach, znajdują się listy nauczycieli, którzy uczyli w szkole. Dane z lat 1924-1928 są niepełne.

Z. Olszewski w swojej publikacji wymienia zapamiętanych przez siebie pedagogów: Ks. Stanisław Dunikowski (były kapelan w Legionach Piłsudskiego, katecheta, kapelan kaplicy zdrojowej), Stanisław Bolesław Dunin-Borkowski (geografia, przyroda), dr Włodzimierz Holejko (łacina, język niemiecki), Władysław Grochal (matematyka), Stanisław Bojarski, małżeństwo Liców (historia), Jan Kucza (język polski), małżeństwo Lityńskich (matematyka, łacina), Antoni Nawara (matematyka, fizyka, ćwiczenia cielesne), Z. Olszewski, Michat od Cyganów, dz. cyt., s. $126-128$ 
stażem pracy należał ks. Stanisław Dunikowski - katecheta, który uczył w szkole od chwili jej powstania do wybuchu wojny ${ }^{19}$.

W wykazach są odnotowani także inni nauczyciele wraz z przedmiotami, których uczyli: Władysław Blarowski (rysunek, prace ręczne, pismo, ćwiczenia cielesne), Jan Baystak (łacina), Maria Echrenkrentzówna (historia), Piotr Greis (historia, geografia), Jan Michał Hans (biologia, fizyka, chemia), dr Zygmunt Karpiński (języki: francuski i niemiecki), Bronisław Kawałek (język niemiecki), Mieczysław Kmiecik (matematyka, fizyka), Józef Kutyba (język polski), Kazimierz Kutyba (ćwiczenia cielesne), Adolf Lassota (matematyka, fizyka), Władysław Łabrida (śpiew), Zofia Mrowiec (śpiew i muzyka), Władysław Misiaszek (matematyka, fizyka), Halina Płoszajówna (historia), Adam Romanowski (historia, geografia, łacina), Eugeniusz Seńkowski (przyrodoznawstwo, chemia, fizyka, ćwiczenia cielesne, geografia), Anna Maria Socha (języki francuski i niemiecki), Stanisław Socha (ćwiczenia cielesne, przygotowanie wojskowe), Władysław Socha (rysunek, prace ręczne, zajęcia praktyczne), Maria Stefankówna (język francuski), Czesław Trybowski (geografia), Maria Wiśniewska (śpiew i muzyka), Wacław Zawadzki (język polski) ${ }^{20}$.

Było jednak wielu profesorów, dla których praca w gimnazjum Wieczorkowskiego stanowiła tylko krótki epizod w ich karierach zawodowych, przyjeżdżali na rok, dwa i sami decydowali o odejściu lub z ich pracy rezygnowano. Jan Mlekodaj, były uczeń gimnazjum, charakteryzuje swoich nauczycieli następująco:

Profesorowie, choć bardzo wymagający, byli wyrozumiali, traktowali nas równo bez względu na status majątkowy rodziców i pochodzenie. Nasze wiadomości wyniesione ze szkół powszechnych okazały się nie takie znów małe, a ci ,arystokraci” byli całkiem miłymi kolegami, którym dorównywaliśmy w nauce, imponując dodatkowo umiejętnością jazdy na nartach ${ }^{21}$.

19 Najdłużej zatrudnieni byli: Stanisław Bolesław Borkowski, Antoni Nawara, Eugeniusz Seńkowski, Władysław Socha, Anna Maria Socha, Jan Kucza, Władysław Misiaszek, Adam Romanowski.

20 Akta Prywatnego Gimnazjum Męskiego Sanatoryjnego dra J. Wieczorkowskiego w Rabce, dz. cyt., sygn.: 29/3564/2, 3, 8-12, 18, 20-21, 23, 23, 26, $32-35,37,38-42,48-51$.

21 Wspomnienia byłych uczniów zebrane zostały przez Lucjana Wolanowskiego i umieszczone w opracowaniu na stronie internetowej: <http://www. lucjanwolanowski.com/index.php?id=287> [dostęp: 20.09.2016]. 
Placówka, którą założył dr Jan Wieczorkowski, powoli zyskiwała uznanie w środowisku i pozytywną ocenę ówczesnych władz szkolnych. Dzięki swojej renomie w 1928 roku szkoła nabyła prawa gimnazjum publicznego i została przemianowana na Prywatne Gimnazjum Sanatoryjne Męskie Dr. Jana Wieczorkowskiego w Rabce ${ }^{22}$. Kuratorium po wizytacji i skrupulatnym sprawdzeniu stanu szkoły wysoko oceniło pracę nauczycieli i organizację tej instytucji, dlatego w roku 1930 nadało gimnazjum pełne prawa szkół państwowych (tzw. kategorię „A”). Powstało więc gimnazjum 8-klasowe, a matura zdawana przez uczniów była uznawana przez wyższe uczelnie w kraju. Uczniowie szkół o niższej kategorii byli zmuszeni do zdawania egzaminu przed komisją państwową (eksternistyczny egzaminu z wszystkich przedmiotów). Lucjan Wolanowski wspomina ten fakt następująco:

Gimnazjum miało kategorię „A”, czyli pełne prawa szkół państwowych. Nie było to takie oczywiste. Matury szkół niższych kategorii nie były uznawane przez uczelnie wyższe, chyba że składało się je na zasadzie eksternistycznym przed komisją państwową, ze wszystkich przedmiotów bez żadnego wyją̧tku. Nasz rocznik (matura ustna 13 maja 1938 roku) był ostatnim produktem dawnego systemu oświatowego. To znaczy, ja nigdy nie byłem w szkole podstawowej (wtedy - zwała się powszechną), czytać i pisać nauczyłem się sam, potem było „komplety”, czyli kilkoro dzieci uczących się prywatnie w kolejnych mieszkaniach. Potem była klasa wstępna i czekało mnie osiem klas gimnazjum męskiego dr. Wieczorkowskiegoo ${ }^{23}$.

Szkoła działała odtąd w oparciu o program Ministerstwa Wyznań Religijnych i Oświecenia Publicznego przygotowany dla gimnazjów państwowych. Porządek dnia uczniów tej placówki był ściśle

22 Według sprawozdania wizytacyjnego prywatnych gimnazjów województwa krakowskiego, w latach 1936-1938 w województwie krakowskim funkcjonowało 50 prywatnych gimnazjów, w tym 19 w samym Krakowie. Poza Krakowem działały w: Białej, Bochni, Chrzanowie, Dąbrowie, Gorlicach, Grybowie, Jaśle, Jordanowie, Krynicy, Nowym Sączu (trzy), Oświęcimiu (dwa), Rakowicach, Rapczycy, Staniątkach, Starym Sączu, Tarnowie (pięć), Wadowicach (trzy), Wieliczce, Zakopanem i w Rabce (trzy). Oprócz gimnazjum Wieczorkowskiego w Rabce działało Prywatne Gimnazjum Żeńskie im. św. Teresy i Prywatne Gimnazjum Żeńskie Zgromadzenia Sióstr Nazaretanek. Zob. Akta Kuratorium Okręgu Szkolnego Krakowskiego. Zespół 1342, sygnatura KOSK 32,33, złożone w Archiwum Państwowym, Delegatura w Spytkowicach.

23 Wspomnienia Lucjana Wolanowskiego, <http://www.lucjanwolanowski. com/index.php?id=287> [dostęp: 20.09.2016]. 
określony, jednak ze względu na specyfikę (łączenie nauki z procesem leczenia) program był nieco zmodyfikowany. Lekcje były krótsze (40-minutowe), godziny dydaktyczne były wielokrotnie dzielone werandowaniem, a przy dobrej pogodzie zajęcia lekcyjne odbywały się na świeżym powietrzu. Sporo uwagi poświęcano zajęciom nadobowiązkowym, takim jak: lekcje muzyki, teatr uczniowski, zajęcia plastyczne, zajęcia techniczne, gry towarzyskie, a przede wszystkim zajęcia sportowe (tenis, siatkówka, koszykówka, piłka ręczna, lekkoatletyka, pływanie, narciarstwo, saneczkarstwo, Yyżwiarstwo).

Jak na tego typu placówkę przystało, oprócz dydaktyki i wychowania bardzo ważną rolę odgrywało leczenie; wykorzystywano lecznicze działanie klimatu Rabki, serwowano kąpiele jodowo-solankowe, gazowe i borowinowe. Poza tym stosowano lampy kwarcowe, diatermie i inhalacje. Uczniowie gimnazjum byli pod stałą opieką lekarza. W szkole dbano o morale uczniów i o ich praktyki religijne, jednak przy zachowaniu tolerancji religijnej (apel poranny połączony z modlitwą, obiad i kolacja poprzedzona modlitwą, modlitwa przed snem). Dużo uwagi poświęcano żywieniu młodzieży, uczniowie otrzymywali pięć posiłków dziennie, posiłki były kaloryczne i zdrowe, korzystano przy tym z plonów własnego ogrodu warzywno-owocowego oraz z wyrobów swojej mleczarni.

Gimnazjum Wieczorkowskiego cieszyło się wielkim powodzeniem ze względu na wysoki poziom nauczania, który zawdzięczało odpowiedniemu doborowi nauczycieli, dobrze wyposażonej bibliotece szkolnej, w której liczba dostępnych pozycji ciągle ulegała zwiększeniu (1936 1265 woulminów, 1937 - 1400, 1938 - 1500, 1939 - 1550). Właściciel szkoły inwestował w bazę dydaktyczną, nic więc dziwnego, że władze oświatowe utrzymały swoją wysoką ocenę po przeprowadzeniu kolejnej kontroli w roku 1936. Wizytatorka Maria Chrzanowska, po pobycie w szkole w dniu 21 marca 1936 roku, wystawiła szkole bardzo dobrą ocenę, wskazując na kompetencje dyrektora sprawnie organizującego pracę szkoły: „[...] to człowiek inteligentny, energiczny organizator. Dobrze dobiera pracowników i umie od nich wiele wymagać. Omawiał szczegółowo wszystkie wizytowane lekcje z nauczycielami w sposób, nienasuwający zastrzeżeń. Dba bardzo o poziom szkoły i o jej rozwój”24.

24 Protokól powizytacyjny Kuratorium Okręgu Szkolnego Krakowskiego. Zespół 1342, sygn. KOSK 32. 
W szkole funkcjonowało kilka pracowni. W zachowanych dokumentach mamy spis inwentaryzacyjny, jaki wykonano podczas wizytacji w 1937 roku. Odnotowano wówczas istnienie wyposażonych pracowni: religijnej, polonistycznej ze sceną, filologicznej, języków obcych, matematyczno-fizycznej, geograficzno-historycznej, biologicznej, zajęć praktycznych oraz świetlicy. Każda z pracowni wyposażona była we własną bibliotekę. W 1938 roku rozpoczęto budowę sali gimnastycznej oraz uruchomiono małokalibrową świetlicę dla potrzeb przysposobienia wojskowego. W szkole w latach 1936-1939 funkcjonowały także różne koła: świetlicowe, biblioteczne, sportowe, fotograficzne, przyrodnicze, literackie, koło Czerwonego Krzyża, Liga Ochrony Przyrody oraz drużyna harcerska ${ }^{25}$.

\section{Uczniowie jako podmiot troski założyciela i właściciela szkoły}

Mimo że formalnie szkoła została powołana do życia w 1924 roku, młodzież rozpoczęła naukę rok później. W pięciu klasach (wstępnej, pierwszej, drugiej, czwartej oraz piątej) uczyło się 20 uczniów, wszyscy deklarowali wyznanie rzymskokatolickie. Klasa wstępna liczyła trzech uczniów (w wieku 8-9 lat, byli to chłopcy na stałe mieszkający w Warszawie), w klasie pierwszej naukę pobierało pięciu uczniów (w wieku 10-13 lat, mieszkających na stałe w województwie lubelskim, warszawskim, wrocławskim, jeden uczeń był z Poznania). Do klasy drugiej chodziło ośmiu uczniów (w wieku 11-14 lat oraz jeden osiemnastolatek, na stałe mieszkający w Łodzi, Warszawie, Krakowie, Wrocławiu, Komornie pod Lwowem). Jeden uczeń - Tadeusz Fuss był wychowankiem Jana Wieczorkowskiego, stąd mieszkał w jego domu. Klasa czwarta miała dwóch uczniów (w wieku 13-14 lat, pochodzących z Kalisza i Warszawy), podobnie mało liczna była klasa piąta - uczyło się w niej dwóch uczniów (w wieku 15-16 lat, mieszkających na stałe w Zakopanem i Żyrardowie).

Liczba uczniów i klas w kolejnych latach była uzależniona od tego, kto akurat przebywał w Rabce na leczeniu sanatoryjnym. Nie każdy mógł trafić do tej placówki, nie przyjmowano do niej chłopców chorych zakaźnie (także z gruźlicą) oraz chorych umysłowo.

25 Akta Kuratorium Okręgu Szkolnego Krakowskiego. Zespół 1342, sygn. KOSK 32, 33. 
Uczniów przyjmowano na podstawie egzaminu wstępnego, który przeprowadzano w czerwcu lub w okresie pomiędzy 25 sierpnia a 15 września. Po zakończeniu pierwszego półrocza egzamin przeprowadzano w pierwszych dwóch tygodniach stycznia. Młodzież w szkole z internatem przebywała nie krócej niż przez pół roku, przybywała z całej Polski, także ze Śląska i Prus.

Ze względu na wysokie czesne, na taką edukację stać było tylko uczniów z bogatych rodzin, arystokracji, ziemiaństwa, sfer przemysłowo-kupieckich, finansjery czy też dzieci rodziców wykonujących intratne zawody inteligenckie (architekci, adwokaci). Równocześnie gimnazjum kształciło synów rabczańskich górali, którzy traktowani byli na równi $z$,dobrze urodzonymi” kolegami, chociaż w opłacie za czynsz korzystali ze sporych zniżek, a niekiedy byli całkowicie z opłat zwalniani (czynsz bez internatu wynosił od 30 do 60 zl) ${ }^{26}$. Brak jest dokumentów, które w sposób jednoznaczny określałyby wysokość kosztów edukacji w gimnazjum. O wysokości opłat za pobyt w placówce decydował osobiście dyrektor Wieczorkowski. Przy ustalaniu czesnego możemy się tylko opierać na relacjach byłych uczniów:

Mimo że w Nowym Targu i Jordanowie istniały gimnazja państwowe, które nie pobierały tzw. czesnego, gimnazja rabczańskie cieszyły się wielkim powodzeniem ze względu na wysoki poziom nauczania i wychowania, uczęszczała tutaj młodzież z całej Rzeczypospolitej, córki i synowie tzw. wyższych sfer, a więc arystokracji, ziemian i wykonujących wolne zawody. Nie bez znaczenia była tu wysokość czesnego, które u Wieczorkowskiego wynosiło 90 zł miesięcznie, przy średniej płacy np. na kolei czy poczcie nieco ponad 100 zł. Podkreślić tu wypada wielką wyrozumiałość dyrektora, który gorzej sytuowanym rodzicom najczęściej z terenu Rabki, obniżał opłatę miesięczną za ucznia do 50 a nawet 30 zł. Gimnazjum dra Wieczorkowskiego, obok działalności dydaktycznej, zapewniało potrzebującej młodzieży opiekę sanatoryjną w tzw. instytucie, obejmującą opiekę lekarską, pielęgniarską, mieszkanie i wyżywienie - za jedyne 210 zł miesięcznie. Warunki lecznicze były tu wprost idealne. $\mathrm{Na}$ terenie wspaniale utrzymanego rozległego parku, w kilku budynkach dawnego dworu Zubrzyckich mieściły się klasy i pracownie gimnazjalne oraz pokoje mieszkalne dla internistów, którzy ucząc się byli pod stałą opieką lekarską, a w podziale godzin mieli nawet werandowanie ${ }^{27}$.

H. Urbanowski, Poczatki dziatalności Liceum Ogólnoksztatcacego im. E. Romera w Rabce-Zdroju. Szkota z tradycja, „Wieści Rabczańskie”2014, nr 1(17), s. 11. od 1.09.1935 roku został uczniem pierwszej klasy gimnazjum, zebrane 
Charakter szkoły sprawiał, że pobierali w niej naukę chłopcy zjeżdżający do Rabki z całej Polski. Stąd uczniowie gimnazjum byli bardzo zróżnicowani pod względem statusu społecznego i materialnego. W protokole pokontrolnym wizytator Stanisław Konar odnotował tę różnorodność i podkreślił dobrą pracę wychowawczą pedagogów z tej szkoły:

Współżycie młodzieży z różnych środowisk społecznych stanowi jeden $\mathrm{z}$ problemów pracy wychowawczej w szkole i nastręcza dużo sposobności do wychowywania w duchu obywatelsko-państwowym. Różnica pochodzenia i życiowych warunków uczniów wywołuje niekiedy pewne trudności, rozumnie jednak i z taktem prowadzona praca wychowawcza niewątpliwie oddziaływa w pożądanym kierunku. Praca wychowawcza zorganizowana przy pomocy samorządów klasowych i kilku szkolnych organizacji. Troskliwszą opieką nauczycieli i ściślejsze współżycie z młodzieżą ułatwia fakt, że znaczna część grona mieszka w najbliższym sąsiedztwie szkoły i dużo czasu w niej spędza. $Z$ organizacji najwięcej do wzajemnego zbliżania młodzieży przyczynia się koło świetlicowe prze pomocy zebrań, imprez i uroczystości. Do pracy charytatywnej wdraża się młodzież w Kole Czerwonego Krzyża. Konkretne wyniki pracy daje koło biblioteczne, pomagające bibliotekarzowi szkolnemu ${ }^{28}$.

\begin{tabular}{|c|c|c|c|c|c|c|c|c|c|c|c|}
\hline & $\begin{array}{c}\text { Liczba } \\
\text { klas }\end{array}$ & $\begin{array}{c}\text { Liczba } \\
\text { ucz- } \\
\text { niów }\end{array}$ & $\begin{array}{c}\text { Klasa } \\
\text { wstęp- } \\
\text { na }\end{array}$ & $\begin{array}{c}\text { Klasa } \\
\text { I }\end{array}$ & $\begin{array}{c}\text { Klasa } \\
\text { II }\end{array}$ & $\begin{array}{c}\text { Klasa } \\
\text { III }\end{array}$ & $\begin{array}{c}\text { Klasa } \\
\text { IV }\end{array}$ & $\begin{array}{c}\text { Klasa } \\
\text { V }\end{array}$ & $\begin{array}{c}\text { Klasa } \\
\text { VI }\end{array}$ & $\begin{array}{c}\text { Klasa } \\
\text { VII }\end{array}$ & $\begin{array}{c}\text { Klasa } \\
\text { VIII }\end{array}$ \\
\hline $1925 / 26$ & 5 & 20 & $*$ & $*$ & $*$ & & $*$ & $*$ & & & \\
\hline $1926 / 27$ & 6 & 29 & & $*$ & $*$ & $*$ & $*$ & $*$ & $*$ & & \\
\hline $1927 / 28$ & 6 & 54 & & $*$ & $*$ & $*$ & $*$ & $*$ & $*$ & & \\
\hline $1928 / 29$ & 6 & 59 & & $*$ & $*$ & $*$ & $*$ & $*$ & $*$ & & \\
\hline $1929 / 30$ & 5 & 51 & & $*$ & $*$ & $*$ & $*$ & $*$ & $*$ & & \\
\hline $1930 / 31$ & 6 & 63 & & $*$ & $*$ & $*$ & $*$ & $*$ & $*$ & & \\
\hline $1931 / 32$ & 6 & 53 & & $*$ & $*$ & $*$ & $*$ & $*$ & $*$ & & \\
\hline
\end{tabular}

Tabela 1.

Liczba uczniów i klas w gimnazjum w latach 1925-1939

przez L. Wolanowskiego. Zob. <http://www.lucjanwolanowski.com/index. php?id=287 > [dostęp: 20.09.2016].

28 Protokół z kontroli przeprowadzonej w szkole w dniach 25-27.02.1937 roku przez wizytatora Kuratorium Okręgu Szkolnego Krakowskiego. Zespół 1342, sygn. KOSK 32, 33. 


\begin{tabular}{|c|c|c|c|c|c|c|c|c|c|c|c|}
\hline & $\begin{array}{c}\text { Liczba } \\
\text { klas }\end{array}$ & $\begin{array}{c}\text { Liczba } \\
\text { ncz- } \\
\text { niów }\end{array}$ & $\begin{array}{c}\text { Klasa } \\
\text { wstęp- } \\
\text { na }\end{array}$ & $\begin{array}{c}\text { Klasa } \\
\text { I }\end{array}$ & $\begin{array}{c}\text { Klasa } \\
\text { II }\end{array}$ & $\begin{array}{c}\text { Klasa } \\
\text { III }\end{array}$ & $\begin{array}{c}\text { Klasa } \\
\text { IV }\end{array}$ & $\begin{array}{c}\text { Klasa } \\
\text { V }\end{array}$ & $\begin{array}{c}\text { Klasa } \\
\text { VI }\end{array}$ & $\begin{array}{c}\text { Klasa } \\
\text { VII }\end{array}$ & $\begin{array}{c}\text { Klasa } \\
\text { VIII }\end{array}$ \\
\hline $1932 / 33$ & 6 & 52 & & $*$ & $*$ & $*$ & $*$ & $*$ & $*$ & & \\
\hline $1933 / 34$ & 6 & 58 & $*$ & $*$ & $*$ & & $*$ & $*$ & $*$ & & \\
\hline $1934 / 35$ & 5 & 73 & $*$ & $*$ & $*$ & & $*$ & $*$ & $*$ & & \\
\hline $1935 / 36$ & 4 & 79 & & $*$ & $*$ & $*$ & & & $*$ & & \\
\hline $1936 / 37$ & 5 & 110 & & $*$ & $*$ & $*$ & $*$ & & & $*$ & \\
\hline $1937 / 38$ & 5 & 119 & & $*$ & $*$ & $*$ & $*$ & & & & $*$ \\
\hline $1938 / 39$ & 4 & 113 & & $*$ & $*$ & $*$ & $*$ & & & & \\
\hline
\end{tabular}

Źródło: opracowanie własne ${ }^{29}$.

Z dostępnych dokumentów wynika, że w kolejnych latach liczba uczniów systematycznie wzrastała (por. tabela 1), osiągając 119 osób w roku szkolnym 1937/38 (a w ostatnim roku przed wybuchem wojny o sześciu uczniów mniej). Odnotowany w roku szkolnym 1936/37 znaczny wzrost liczby uczniów był związany z otwarciem dodatkowego internatu. Założył go o. Karol van Oost, belgijski benedyktyn dzierżawiący od miejscowego bogatego chłopa willę "Jaworzyna”. $\mathrm{W}$ internacie św. Benedykta zamieszkali chłopcy z najbogatszych i wyłącznie katolickich rodzin, znający dobrze język francuski, który obowiązywał w rozmowach $z$ wychowawcami w habitach. Uczniowie, zwani w żargonie szkolnym „eksternistami”, dojeżdżali z „Jaworzyny” do szkoły dorożkami lub na rowerach (zimą saniami) i tam odbywali wspólne lekcje $z$,internistami” mieszkającymi na poddaszu dworu $^{30}$. Z roku na rok można było zaobserwować wzrost liczby uczniów niemieszkających ani we dworze, ani też w internacie benedyktynów. Rodzice wynajmowali dla nich prywatne kwatery w Rabce. ${ }^{31}$

29 Akta Prywatnego Gimnazjum Męskiego Sanatoryjnego dr J. Wieczorkowskiego w Rabce, sygn.: 29/3564/2, 3, 8-12, 18, 20-21, 23, 23, 26, 32-35, 37, 38-42, 48-51.

30 K. Ceklarz, J. Ceklarz, J. Gaweł, P. Kuczaj, H. Urbanowski, Rabka. Ztote lata Rabki-Zdroju, dz. cyt., s. 124.

31 Akta Prywatnego Gimnazjum Męskiego Sanatoryjnego dra J. Wieczorkowskiego w Rabce, sygn. 29/3564/48-51. 


\begin{tabular}{|l|c|c|c|c|}
\hline & $1931 / 32$ & $1932 / 33$ & $1934 / 35$ & $1938 / 39$ \\
\hline internat we Dworze & 28 & 37 & 33 & 27 \\
\hline internat oo. Benedyktynów & 20 & 22 & 23 & 23 \\
\hline stancje prywatne & 43 & 40 & 50 & 42 \\
\hline uczniowie miejscowi & 2 & 7 & 13 & 21 \\
\hline
\end{tabular}

Tabela 2.

Zakwaterowanie uczniów gimnazjum w latach 1936$-1939$

Źródło: opracowanie własne na podstawie wykazów Kuratorium Okręgu Szkolnego Krakowskiego ${ }^{32}$.

Należy odnotować, że liczba uczniów pochodzących z Rabki i sąsiednich miejscowości dynamicznie rosła (por. tabela 2). O ile w roku szkolnym1931/32 było ich zaledwie dwóch (Jan Ceremuga ze Skawy oraz Emanuel Gries, syn kupca żydowskiego z Rabki), to w roku szkolnym 1932/33 naukę pobierało już siedmiu, $13 \mathrm{w}$ roku szkolnym 1934/1935, a 21 zostało przyjętych w roku szkolnym 1938/39. Na naukę w gimnazjum mogła sobie pozwolić młodzież dobrze sytuowana, zatem najczęściej byli to synowie miejscowych lekarzy, kolejarzy, właścicieli ziemskich, bogatych Żydów, kierowników instytucji, zamożnych przedsiębiorców i artystów. Na liście uczniów odnajdziemy także synów rolników. Niestety nie można dzisiaj ustalić wysokość czesnego, jakie płacili mieszkańcy Rabki i okolic. Wiemy jedynie ze wspomnień, że byli często zwalniani z całkowitej opłaty bądź płacili kwoty symboliczne ${ }^{33}$.

W aktach szkoły znajdują się wykazy uczniów pobierających naukę w gimnazjum Wieczorkowskiego. Pozostali też w pamięci kolegów, którzy na kartach książek opisali wspólne przeżycia szkolne chłopców, których losy połączyła kiedyś wspólna edukacja. Zdzisław Olszewski (uczeń szkoły od roku 1927) ${ }^{34}$ w wydanej w 1985 roku publikacji wymienia po nazwisku i charakteryzuje niektórych kolegów z klasy: Tadeusz Fuss (późniejszy malarz i rzeźbiarz), Sławomir Nitecki (z Łodzi), Adam Hubiszta (syn adwokata z Rabki), Adam i Andrzej Sierakowscy (hrabiowie z Prus Wschodnich), Zbyszko

32 Kuratorium Okręgu Szkolnego Krakowskiego. Zespół 1342, sygn. KOSK $32,33$.

33 Akta Prywatnego Gimnazjum Męskiego Sanatoryjnego dra J. Wieczorkowskiego w Rabce, dz. cyt.

34 Z. Olszewski, Michat od cyganów, dz. cyt., s. 106-108, 131, 147. 
Nowak, Jan Ekier (późniejszy znany pianista), Janusz Minkiewicz (satyryk i poeta), Ryszard Riess (z zamożnej rodziny adwokackiej z Kielc), Zdzisław Narbutowicz (z Warszawy).

Także Lucjan Wolanowski wspomina swoich kolegów, którzy tak jak on 13 maja 1938 roku zdali dużą, ustną maturę po ósmej klasie gimnazjum. Wśród wymienionych przez niego znaleźli się: Jerzy Loewenstein (wnuk barona, który zasiadał w Wiedniu w Izbie Panów, matka $z$ domu Poznańska, pochodząca z rodziny łódzkich milionerów), Henryk hr. Sobański (z Guzowa koło Żyrardowa), Gustaw Schreer (Niemiec z Łodzi, syn bogatego przemysłowca, zginął jako pilot Luftwaffe w czasie walk nad Kanałem La Manche), Michał hr. Sobański, Gabriel Rechowicz (syn architekta ze Lwowa, znany malarz), Aleksander Larisch-Nimsdorf, Józef hr. Jezierski (pochodził z bardzo bogatego rodu warszawskiego, mieszkającego na Placu Zamkowym), Jan Szymański (miejscowy góral), Franciszek Gros vel Król (mieszkaniec Krakowa, z rodziny urzędnika przemysłu chemicznego), Jerzy Christ (syn lekarza z Rabki), Jan Ceremuga (miejscowy góral), Jan Papierz (góral, po wojnie więzień polityczny), Zbigniew Mieszkowski (syn właściciela wielkiego majątku Skrwilno koło Sierpca), Jacek Kaden (syn Adama Kadena, współwłaściciela Rabki, zamordowany przez Niemców w Auschwitz) ${ }^{35}$.

Uczniami rabczańskiego gimnazjum były także inne, równie wybitne postaci, takie jak: książę Franciszek Radziwiłł, Adam i Andrzej Sierakowscy (hrabiowie z Prus Wschodnich) czy gimnazjaliści, którzy dzięki wykształceniu zdobyli znaczącą pozycję w świecie literatury, sztuki, nauki czy polityki: Lucjan Kon (czyli Lucjan Wolanowski, pisarz, reporter, podróżnik i tłumacz), Aleksander Ziemny (czyli Aleksander Keiner, poeta, prozaik, reportażysta, tłumacz literatury pięknej z języka angielskiego, rosyjskiego, ukraińskiego i hebrajskiego), Andrzej Tymowski (socjolog, profesor Uniwersytetu Warszawskiego), Aleksander Małachowski (wicemarszałek Sejmu w latach 1993-1997), Stanisław Mlekodaj (wiceminister zdrowia, profesor medycyny), Jan Stanisław Ekier (pianista, pedagog i kompozytor, profesor sztuk muzycznych), Jacek Woźniakowski (historyk sztuki, pisarz, eseista, publicysta, dziennikarz, edytor, wydawca, tłumacz literatury pięknej, prezydent Krako-

35 Wspomnienia Lucjana Wolanowskiego, <http://www.lucjanwolanowski. com/index.php?id=287> [dostęp: 20.09.2016]. 
wa w latach 1990-1991, profesor KUL), Janusz Minkiewicz (pisarz, satyryk, absolwent Uniwersytetu Warszawskiego) ${ }^{36}$.

\section{Zamiast zakończenia: słowo o Janie Wieczorkowskim, założycielu szkoły}

Dr Jan Wieczorkowski był znakomitym organizatorem i wybitnym pedagogiem, swoją postawą oraz własnym działaniem zdobył autorytet wśród uczniów i cieszył się szacunkiem grona pedagogicznego. Był osobą oczekującą od zatrudnionych pracowników profesjonalizmu i rzetelności. Stawiał też wymagania uczniom oddanym przez rodziców pod jego opiekę, jednak przede wszystkim nie oszczędzał siebie. Oddany był idei zorganizowania dobrej szkoły, dającej uczniom możliwość nauki w trakcie prowadzenia leczenia sanatoryjnego. Poświęcił się pracy, która była sensem jego życia do tego stopnia, że po upaństwowieniu placówki nie chciał dalej żyć, bo nie wyobrażał sobie bowiem funkcjonowania bez niej. Jak wspominają uczniowie:

Był człowiekiem o rozleglej wiedzy, wymagającym wiele od uczniów i współpracowników, ale przede wszystkim od siebie. Odznaczał się ponadto zdolnościami organizacyjnymi. Poziom nauczania w prowadzonej przez niego szkole był wysoki; mimo trudności powojennych (m.in. całkowity brak podręczników), wielu jej absolwentów kończyło potem studia wyższe i uzyskiwało stopnie naukowe ${ }^{37}$.

To postać wybitna, dzięki jego talentowi pedagogicznemu i organizacyjnemu Rabka zyskała swoją renomę jako miejsce, w którym dzieci mogły odzyskać zdrowie i zdobyć wiedzę, a z nią po powrocie do domu kontynuować dalsze wykształcenie. Swoim działaniem spowodował, że w latach 1924-1939 Gimnazjum Męskie Sanatoryjne dr. Jana Wieczorkowskiego było placówką nowatorską pod każdym względem, cieszącą się bardzo dobrą opinią ze względu na świetną organizację, właściwy dobór nauczycieli i, co za tym idzie, wysokim poziomem nauczania oddanych pod opiekę uczniów. Założyciel szkoły to także postać znacząca dla rozwoju

36 K. Ceklarz, J. Ceklarz, J. Gaweł, P. Kuczaj, H. Urbanowski, Rabka. Ztote lata Rabki-Zdroju, dz. cyt., s. 124.

37 M. Olszewska, E. Trybowska, Stownik biograficzny Rabki, dz. cyt., s. 318. 
Rabki jako miejscowości uzdrowiskowej, jednak niestety z biegiem lat przez jej mieszkańców zapomniana ${ }^{38}$.

\section{BIBLIOGRAFIA}

Akta Kuratorium Okręgu Szkolnego Krakowskiego. Zespół 1342, sygn.: KOSK 32, 33, złożone w Archiwum Państwowym, Delegatura w Spytkowicach.

38 W czasie II wojny światowej Jan Wieczorkowski przez dwa lata był więziony przez Niemców (1940-1942). Po wyzwoleniu Rabki przez armię radziecką 28 stycznia 1945 roku przystąpił do reaktywacji gimnazjum. Pożar dworu (wybuchy bomb, podpalenia i grabież przez uciekających Niemców) spowodowały, że z bardzo bogatej bazy przedwojennej nie pozostało prawie nic. Już od połowy lutego 1945 roku przystąpił więc do organizacji nowego gimnazjum i liceum według przedwojennych programów. Rozpoczynał dzieło praktycznie od zera, stary dwór nie nadawał się do odbudowy, majątku szkoły także nie można było odzyskać. Należy podkreślić, że tylko jemu udało się reaktywować jedną z trzech szkół średnich, które funkcjonowały w Rabce przed wojną. Naukę w niej rozpoczęto już 19 marca 1945 roku w nowej szkole o nazwie Prywatne Liceum i Gimnazjum Koedukacyjne Dra Jana Wieczorkowskiego w Rabce (w czterech oddziałach klasy pierwszej, po jednym oddziale klasy drugiej i trzeciej oraz dwóch oddziałach klasy czwartej gimnazjum, a także dwóch oddziałach liceum: klasa humanistyczna i matematyczno-fizyczna). Istnienie prywatnego liceum w czasach powojennych było zagrożone, ponieważ władze oświatowe PRL nie zezwalały na funkcjonowanie prywatnych placówek w przestrzeni publicznej. Dr Jan Wieczorkowski próbował ratować swoją szkołę przez przekazanie jej pod patronat organizacji społecznej, jaką był Związek Samopomocy Chłopskiej w Rabce. Od 1 września 1949 roku liceum jako jedyna szkoła w Polsce działała pod tego typu patronatem. $Z$ punktu widzenia prawnego przestała być szkołą prywatną, kierowaną przez jedną osobę, czyli założyciela i dotychczasowego właściciela. Jednak dzięki temu zabiegowi taktycznemu jeszcze cztery lata po wojnie Wieczorkowski miał na nią jakiś wpływ. Prywatna Szkoła Ogólnokształcąca Stopnia Licealnego (koedukacyjna) Związku Samopomocy Chłopskiej w Rabce miała swojego mecenasa i „opiekuna”. Nauka w liceum trwała cztery lata (po siedmiu latach nauki w szkole podstawowej) i kończyła się egzaminem dojrzałości, który dawał uprawnienia do podjęcia studiów wyższych. W dniu 20 marca 1950 roku nowy „właściciel” szkoły - Związek Samopomoc Chłopska - przekazał jednak cały majątek placówki (wraz z biblioteką) na własność Ministerstwu Oświaty i zrzekł się kurateli nad szkołą. Był to faktyczny koniec prywatnego liceum dr. Jana Wieczorkowskiego. W dniu 29 lipca 1950 roku, po upaństwowieniu szkoły (decyzją Henryka Jabłońskiego), mieszkańcy Rabki zostali zaskoczeni nagłą wiadomością o tragicznej śmierci dyrektora dr Jana Wieczorkowskiego. Władza Ludowa nie kochała dawnych właścicieli ziemskich, ludzi zamożnych, kojarzonych z poprzednim systemem, zatem nie dziwił fakt, że nikt z ówczesnych władz oświatowych nie wziął udziału w jego pogrzebie. 
Akta Prywatnego Gimnazjum Męskiego Sanatoryjnego dra J. Wieczorkowskiego w Rabce, sygn.: 29/3564/2, 3, 8-12, 18, 20-21, 23, 23, 26, 32-35, 37, 38-42, 48-51, 29/3564/48-51.

Czarnecka A.,Historia szkoty, <http://www.sp2.rabka.p1/historia/historia.html>.

Ceklarz K., Ceklarz J., Gaweł J., Kuczaj P., Urbanowski H, Rabka. Ztote lata Rabki-Zdroju, Studio Plan Art, Rabka-Zdrój 2014.

Historia Uzdrowiska Rabka,cz.2,<http://www.rabka.pl/index.php?dzial=2\&dok=2>.

Kowalczyk K., Miejsca kultu religijnego w Rabce Zdroju, Instytut Teologiczny Księży Misjonarzy, Kraków 2003.

Nawratil E., Trybowski C., Rabka i okolice oraz krótki przewodnik po Beskidzie Wyspowym i Gorcach, Wydawnictwo Zakładu Zdrojowego w Rabce, Kraków 1938.

Olszewska M., Trybowska E., Stownik biograficzny Rabki, Oficyna Wydawnicza „Wierchy”, Kraków - Rabka Zdrój 2012.

Olszewski Z., Michat od Cyganów, Krajowa Agencja Wydawnicza, Kraków 1985.

Prospekt Gimnazjum Męskiego Sanatoryjnego z Internatem dr. J. Wieczorkowskiego w Rabce, w archiwum szkolnym LO im. E. Romera w Rabce-Zdrój.

Statut Internatu Prywatnego Gimnazjum Męskiego dr. Jana Wieczorkowskiego w Rabce, w archiwum szkolnym LO im. E. Romera w Rabce-Zdrój.

Urbanowski H., Początki dziatalności Liceum Ogólnoksztatcącego im. E. Romera w Rabce-Zdroju. Szkota z tradycja, „Wieści Rabczańskie” 2014, nr 1(17).

Urbanowski H., Takie byty Zdroju początki. Ztote lata Rabki Zdroju, Wydawnictwo MOK, Rabka-Zdrój 2014.

<http://www.lucjanwolanowski.com/index.php?id=287>.

<http://www.rabka.pl/index.php?dzial=3>.

\section{ADRES DO KORESPONDENCJ}

Dr hab. Maria Marta Urlińska

Akademia Ignatianum w Krakowie

Wydział Pedagogiczny, Instytut Nauk o Wychowaniu

marta.urlinska@gmail.com

Mgr Marek Świder

Akademia Ignatianum w Krakowie

Wydział Pedagogiczny

dyrektor@romer.nowotarski.pl 